\title{
ADRENERGIC BLOCKING AGENTS IN SHOCK ${ }^{1}$
}

WolfGang E. SPOEREL, M D, F.R.C P.(c) ${ }^{2}$

IN RECENT YEARS a number of agents have been developed which block the sympathetic nervous system These agents can be divided into two groups according to their site of action. ganglionic blocking agents block the transmission of impulses at the ganglonic synapses, adrenergic blocking agents act on the sympathetic end organs and reduce or reverse the pressor effect of adrenalin The latter group includes agents like dibenamine, dibenzyline, regitune, priscoline, hydergine, and chlorpromazine (Largactil)

Especially for chlorpromazine and more recently for hydergine, claims have been made that these agents would prevent shock caused by haemorrhage and severe trauma or would at least delay the onset of an irreversible state of shock Laborit's (15) concept of artificial hibernation, in which Largactıl plays the principle role, has received wide publicity, particularly in regard to its application in shock. Clinically, adrenergic or ganglionic blocking agents have been advocated for protection against shock and, in addition to blood volume replacement, for the treatment of existing shock $(3,7,17)$ The reports of such treatments appear to be noteworthy and one has the impression that adrenergic blocking agents in combination with blood volume replacement would give better results than the present treatment of shock with transfusions and supportive measures The value of many of the publications, particularly those from Europe, is discounted because they are written in a flowery language with specially invented terminology, and because the argumentation is frequently based on very theoretical grounds.

The basic concept for this new approach appears to be this. A diminished blood volume leads to a decrease in venous return and a reduced cardiac output The resulting fall in blood pressure is counteracted by peripheral vasoconstriction, which is induced and possibly maintained by the activity of the sympathetic nervous system including the adrenal medula. This vasoconstriction in reducing the blood flow produces tissue hypoxia, which leads to an increased capillary permeability. Leakage from the capillaries reduces the blood volume further and thus a vicious cycle is set into operation (Fig. 1).

The important concept in this "shockwheel" is that compensatory mechanisms contribute to the progress of shock. Erlanger and Casser (6) in 1919 expressed the view that the increased adrenergic activity in shock was an important factor in the deterioration of the organism. It was later on demonstrated that a continuous infusion of adrenalin could produce shock (8), and a marked rise of the blood level of adrenalin was observed following haemorrhage in dogs (23)

\footnotetext{
1Presented at the combined meeting of Section of Anaesthesia, Ontario Medical Association, and the Ontano Division of the Canadian Anaesthetssts' Society, October 5, 1957, in Hamilton, Ont.

2Department of Anaesthesia and Department of Physiology, University of Western Ontario, London, Ont.
} 


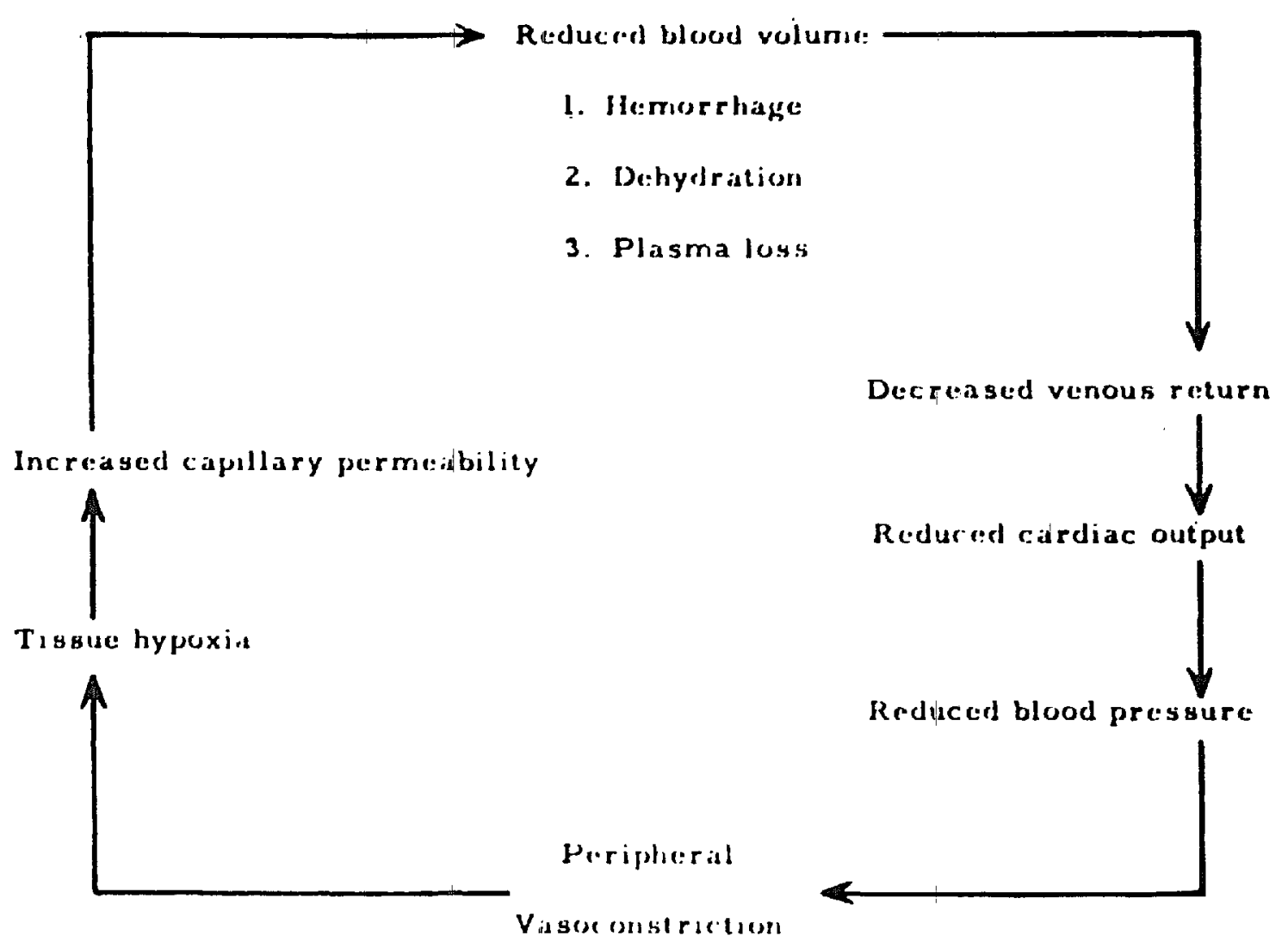

Figure 1. Shock wheel (21).

If such an overactivity of the sympathetic system is important for the production of an.irreversible state of shock, then the pharmacological inhibition of this system should prove beneficial. Experiments on haemorrhagic shock in dogs and rats seemed to demonstrate this. It was shown in a number of studies $(2,12,16$, $18-20,24)$ that the survival rate following a haemorrhagic shock procedure was markedly increased if an agent with an adrenergic blocking effect had been given before or shortly after the haemorrhage. It appeared as if adrenergic blocking agents offered a form of protection against irreversible shock.

Attempts have been made to use these findings as the basis for a new approach to the prevention and treatment of clinical shock $(3,17)$. The results of such a treatment are difficult to judge since no reliable signs exist to determine objectively the severity of a state of shock. Enthusiastic reports have been published in Europe. Laborit's cocktail was tried by the French Army in Indochina, but reports (5) failed to provide convincing results. However, there seemed to be difficulties in the practical handling of this new method. In an attempt to compare the new approach with the "classical" method on patients, Benke (1) concluded that the results with chlorpromazine and hydergine were not convincingly better.

In view of these reports the question is whether we should consider the sympathetic system as potentially dangerous and block it whenever the organism is threatened by severe stress or whethër we may still have some sympathy with it? 
An analysis of experimental haemorrhagic shock leads to some difficulties. Most investigators use a modification of the following procedure to produce a state of shock The animal is bled into a reservoir until the blood pressure falls to a pre-determined mean level $(35-45 \mathrm{~mm}$. $\mathrm{Hg})$. This level is maintained for a certain leng,th of time, and then all the blood is reinfused and the animal observed for surviva.. Following the intial haemorrhage, small volumes of blood have to be withdrawn in order to maintain the hypotension. This is regarded as evidence for vasoconstriction. Towards the end of the hypotensive perod the blood pressure tends to fall further and small amounts of blood have to be reinfused. This phenomenon apparently expresses the beginning of a failure of the compensatory mechanisms.

With this procedure a hypovolemic hypotension is produced, which, if maintained long enough, leads to a state of irreversible shock. In this procedure, only the hypotension is controlled, the hypovolemia can only be measured indirectly by the bleeding volume.

What is the relationshp between blood loss and hypotension under these circumstances? A dog in light Nembutal anaesthesia will maintain an almost normal blood pressure until a considerable volume of blood is lost; \& relatively small blood loss will then produce a severe hypoterision. Yet, attempts to raise the pressure above this low level are very marked in spite of further blood loss When treated with Largactıl ( $2 \mathrm{mg} . / \mathrm{kg}$.) one hour betore the be zinning of haemorrhage, a definite blood pressure response to each bleedir'g can be observed, the low pressure level is reached with less blood loss and attempts to raise the blood pressure are less marked (Fig 2).

This demonstrates the fact, well known to anaesthetists, that the difference between a normal and a "shock-level" of blood pressure corresponds to a relatively small change in blood volume. Inhibition of sympathetic activity produced this shock level of blood pressure with a smaller loss of blood. It might then be postulated that the blood loss which caused a severe hypotension in a treated animal may not be sufficient to produce a dangerous hypotension in an untreated animal. Blood volume studies have indicated that there seems to be a critical degree of hypovolemia which determines the reversibility of a state of shock following haemorrhage (22). Surgically sympathectomized dogs could tolerate severe hypotension longer, but therr tolerance to blood loss was dimmished ( 9 ). Most experimental studies on haemorrhagic shock showed that the bleeding volumes of animals treated before the haemorrhage with blocking agents were smaller than in the untreated controls. Even where the bleeding volumes were equal, the time necessary to withdraw the blood was considerably longer in the treated animals, if a comparable degree of hypotension was maintained (18). Thus, if hypovolemia is regarded as the principal factor in the production of a state of shock, it becomes doubtful whether the treated animals have been subjected to a comparable degree of stress in this type of experiment. Jacob et al. (14) state that the protective effect of dibenamine is mainly due to this reduction of the bleeding volume.

If this difference in bleeding volumes between treated animals and controls represents an important factor, then treatment with these agents should be only 

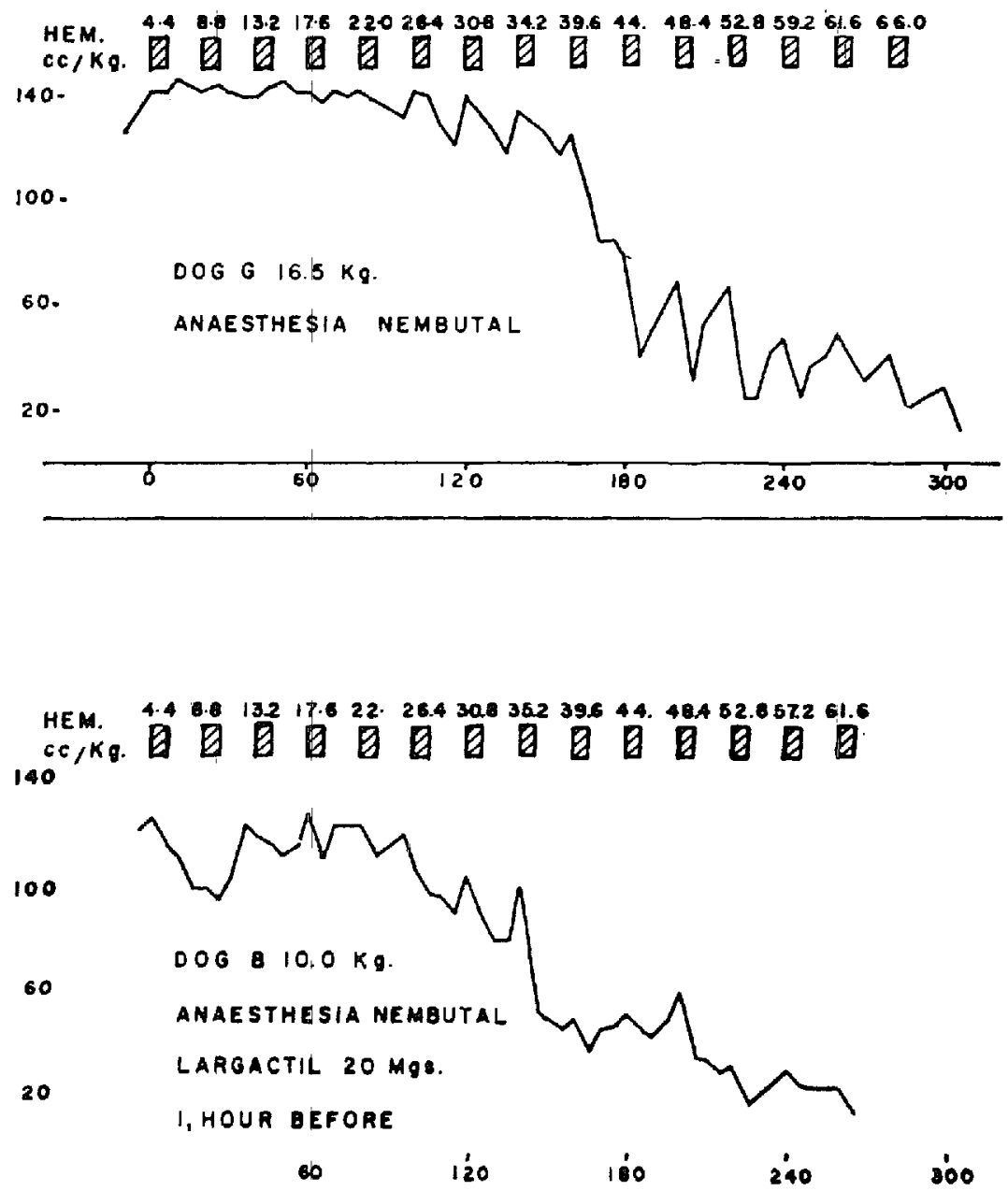

Figure 2. Blood pressure response to haemorrhage (mean pressure). Each column above tracing represents a blood loss of $4.4 \mathrm{cc} / \mathrm{kg}$. Blood pressure in $\mathrm{mm}$. $\mathrm{Hg}$, time in minutes.

of value as long as the bleeding volume can be reduced during the experiment, that is, for a short period following the initial haemorrhage. At the University of Western Ontario studies were carried out to determine the value of adrenergic blocking agents for the treatment of shock. Lotz et al. (16) found that dibenamine and dibenzylene increased the survival when given 30 minutes after the initial haemorrhage. Since the dogs were connected to an open reservoir, the injection of the drug was followed by an uptake of blood into the animal and therefore the total bleeding volumes were less than in the controls. Treatment given 85 minutes after the haemorrhage was without benefit. Priscoline in dogs (10) and chlorpromazine in rats (4) did not increase the survival rate if these agents were given shortly before or together with the reinfusion of the withdrawn blood. Chlorpromazine in dogs, when given at the time of reinfusion, seemed to shorten the time of survival (11): Gowdey et al. (10) conclude that the beneficial effect of adrenergic blocking agents is largely dependent upon an increase in blood volume concomitant with the vasodilatation, and that it could be predicted that in the treatment of clinical haemorrhagic shock these agents 
would be without value or even prejudice survival without a simultaneous replacement of blood volume. These experiments then failed to demonstrate that treatment with transfusion and adrenergic blocking agents combined would be superior to transfusion treatment alone.

The use of adrenergic blocking agents in shock was based on the assumption that an overactivity of the sympathetic system is detrimental in a state of hypovolemia. On the other hand, it has been demonstrated that these same compensatory mechanisms are essential for the maintenance of life in severe hypovolemia. Dogs survived a single massive haemorrhage of 4 per cent of their body weight without volume replacement, but pre-treatment with 2 or $5 \mathrm{mg} . / \mathrm{kg}$. of chlorpromazine made such a haemorrhage uniformly fatál (13). Furthermore, it was found that dogs which were able to raise their blood pressure following a period of controlled haemorrhagic hypotension, that is, to produce a prolonged and more intense vasoconstriction, had a better prognosis (10). Larger bleeding volumes have been reported for survivors in contrast to fatalities in studies of experimental haemorrhagic shock (12), and it may be assumed that this could be in part due to a more intense vasoconstriction. These findings cast some doubt on the concept vasoconstriction in response to hypovolemia is an important factor for the progression of shock into an irreversible state.

It is felt that differently desizned experiments will be necessary to clarify this problem. Certainly adrenergic slocking agents have their place and their indications and the use of drugs like chlorpromazine may be desirable in certain conditions. On the basis of the presently available experimental evidence, however, these agents should only be used for the prevention of operative shock with a good understanding of the circulatory aspects involved. Their use in the treatment of already existing shock does not seem to be justifiable.

\section{SUMMARY}

Premedication with adrenergic blocking agents in experimental haemorrhagic shock pocedure increases the tolerance to hypotension but diminishes the tolerance to hypovolemia. The experimentally observed protection against irreversible shock by such agents appears to be mainly due to a reduced blood loss, which is technically unavoidable in the experimental procedures usually employed.

There is no experimental evidence that adrenergic blocking agents are of value in the treatment of shock at a time when transfusion therapy fails. There is also no indication that a combination of blocking agents and volume replacement would be superior to blood volume replacement alone.

\section{RÉSUMÉ}

Au cours des dernières années, on a préconisé, pour la prévention ou le traitement du choc causé par un traumatisme grave ou une hémorragie, l'association des agents ganglioplégiques et adrénergolytiques comme l'Hydergine et le Largactil avec la restitution du volume sanguin. La justification d'un tel traite- 
ment semble découler du principe que la vasoconstriction consécutive à une réduction de volume sanguir, vasoconstriction attribuable à une activité sympathico-surrénalienne accrue, déclancherait un cercle vicieux qui conduit à un choc irréversible. Ainsi, l'inbibition du sympathique s'avérevart profitable.

Des résultats clıniques nous ont donné l'impression que l'association de l'emploi des agents adrénergolytiques en même temps que la restitution du volume sanguin constituerait un melleur traitement dans le choc. Il est difficile de juger ces cas, car on ne peut pas déterminer objectivement la gravité d'un état de choc clinique.

Chez les animaux en choc hémorragique expérimental, le taux de survivance a semblé supérieur quand on faisait usage avant ou immédiatement après lhémorragie des agents adrénergolytiques. Au cours de ces expériences, on provoque une hypotension prononcée en farsant une saignée dans un réservorr et, à un moment fixé au préalable, on injecte de nouveau le sang soutiré dans la circulation. On a observé, toutefois, chez les anımaux traités que, pour maintenir cette hypotension, 1 fallait retirer des volumes de sang moins considérables. On a pu démontrer, chez les chiens, qu'une dose de Largactil de $2 \mathrm{mg} . / \mathrm{kg}$. administrée avant une hémorragie lente, entraînait une hypotensıon plus prononcée avec une perte de sang moindre et dimınuait la tendance de lorganısme à élever la tension artérielle D'où l'on présume que, à un degré comparable d'hypotension, les anmaux traités garderaient, un plus grand volume sanguin que les anmaux non tratés ou, encore, que l'hypotension, chez les animaux non traités, serait moins prononcée à saignée égale En conséquence, le taux de survivance plus élevé, chez les animaux en hypotension provoquée par une hémorrayie et traités au préalable avec des agents adrénergolytiques, semble être attri juable proncipalement à une perte sanguine inférieure.

Dans les cas où l'on a pratiqué des sargnées d'un volume égal et où l'on a adminiștré des agents adrénergolytiques tardivement au cours de lhypotension confirmée ou encore en même temps que l'injection du sang soutiré, on n'a pas trouvé de différence dans la durée de survie ou cette durée étart plus courte En somme, après ces expénences, on ne peut pas affirmer que l'association de la restıtution du volume sanguin et de l'usage des agents adrénergolytiques soit supérieure à la restitution du volume sanguin seule.

Nous avons l'impression que l'usage des agents adrénergolytıques devrait être limité à la prévention du choc opératoire et seulement si lon a une parfarte compréhension des problèmes circulatoires en cause et que cet usage, dans le cas de choc confirmé, ne semble pas justifiable.

\section{REFERENCES}

1. BENke, A. Schockbehandlung mit klassischen Methoden und mit Antuhustamunica. Der Anaesthesist 6: 65 (1957).

2. BAez, S, ZWEIfACH, B W., \& Shorr, E. Protective Action of Dibenamine against the Fatal Outcome of Hemorrhagic and Traumatic Shock in Rats. Federation Proc. 11. 7 (1952).

3. BobA, A, \& Convense, G. Canglionic Blockade and Its Protective Action in Hemorrhage: A Review. Anaesthesiology 18: 559 (1957).

4. Carruthens, G. F., \& Gowdey, C. W. The Effect of Chlorpromazine given with Reinfusion on the Mortality Rate from Standardized Hemorrhagic Shock in the Rat. Canad. J. Biochem. \& Physiol. 34: 217 (1956). 
5. Chippaux, C. Application of Artificial Hibernation to War Surgery in Indochina. Internat. Rec. Med. \& G. P. Clınics 167: 328 (1954).

6. Erlanger, J., \& Gasser, H. S. Circulatory Fallure due to Adrenaline. Am. J. Physiol. 49: 345 (1919).

7. Fatrer, - G. The Role of Hibernation in the Prevention and Treatment of Surgical Shock. Anest 1. \& Analg. 34: 250 (1955).

8. Fremanan, N. E., Freedman, N., \& Minker, C. C. Production of Shock by Prolonged Contunuous Injection of Adrenaline in Unanaesthetized Dogs. Am. J. Physiol. 131: 545 (1941).

9. Freman, N. E.; Schaffer, S. A.; Schechter, A. E., \& Holling, H. E. The Effect of Total Sympathectomy on the Occurrence of Shock from Hemorrhage. J. Clin. Invest. 17: 359 (1938).

10. Gowdey, C. W., Pearce, J. W., \& Stevenson, J. A. F. Effect of Tolazoline in Hemorrhage Hypotension in Dogs. Canad. J. Biochem. \& Physiol. 34: 951 (1956).

11. GowdeY, C. W., Kruborn, R. M., \& Stevenson, J. A. F Treatment of Haemorrhagic Shock in the Dog with Chlorpromazine and/or Hypothermia. Canad. J. Biochem. \& Physiol. 85 ( $\mathrm{Dec}, 1957$ ).

12. Hershey, S. G., Guccrone, J., \& Zweifach, B. W. Beneficiol Action of Pretreatment with Chlorpromazine on Survival following Graded Hemorrhage in the Rat. Surg., Gynec., \& Obst. 101 431 (1955).

13. Horvath, S. M., Spurr, G. B., \& Blatteis, C. Effect of Chlorpromazine on Survival from a Single Massive Hemorthage. Am. J. Physiol. 185: 505 (1956).

14. Jacob, S., Fruedman, E W., Levenson, S; Glotzer, P, Frank, H. A;; \& Fine, J Antiadrenergic and Anthistaminic Therapy in Hemorrhagic Shock in Dog or Rat Am J. Physiol. 186: 79 (1956).

15. Laborit, H. Artuficial Hubernation. Internat Rec. Med. \& G. P. Clinics 167:321 (1954).

16. Lotz, F., Beck, L., \& Stevenson, J. A. F. The Influence of Adrenergic Blocking Agents, on Metabolic Events in Hemorrhagic Shock in the Dog Canad. J. Biochem. \& Physiol. 33: 741 (1955).

17. Martin, E M. New Approach to Control of Shock. Canad. Anaesth. Soc. J. 2. 222 (1955).

18. Overton, R. C, \& DEB AKEY, M. E. Experimental Observation on the Influence of Hypo thermia and Chlorpromazine on Hemorrhagic Shock. Ann. Surg 143: 439 (1956).

19. Remmigton, J. W., Hammton, W. F, Boyd, G. H, Jr., Hammton, W. F., Jr, \&. CAdDell, H. M. Role of Vasoconstriction un Response of Dogs to Hemorrhage. Am. J Physiol. 161: 116 (1950).

20. Remington, J. W.; Wheeler, N C, Boyd, G. H, Jr.; \& Caddell, H. M. Protectue: Action of Dibenamine after Hemorrhage and after Muscle Trauma. Proc Soc. Exper Biol. \& Med. 69: 150 (1948).

21. Rhoads, J. E., Vaun, W. S ; Parkins, W. M., Ben, M., \& Vars, H. M. Shock. Surg. Clin. North America 1585 (1955).

22. Warcotr, W. W. Blood Volume in Expenmental Hemonhagic Shock. Am. J. Physiol. 143: 247 (1945).

23. Watrs, D. T. Arterial Blood Epine shrine Levels during Hemorrhagic Hypotension ir Dogs. Am. J. Physiol. 184: 271 (19E6).

24. Wiggers, H. C.; Goldberg, H., Roemhild, H., \& Ingrahais, R. C. Impending Hemorrhagic Shock and Course of Events following Administration of Dibenamine. Circulatior. 2: 179 (1950). 